\title{
Language Preferences of Bilingual Indigenous Children to Label Items of Their Drawings: Draw and Write Technique
}

\author{
Miguel Angel Saritama Valarezo, Isabel Alvarez ${ }^{*}$ \\ Department of Systematic and Social Pedagogy, Autonomous University of Barcelona, Spain
}

Received February 10, 2020; Revised March 18, 2020; Accepted March 28, 2020

Copyright $\odot 2020$ by authors, all rights reserved. Authors agree that this article remains permanently open access under the terms of the Creative Commons Attribution License 4.0 International License

\begin{abstract}
This article examines the language in indigenous students within bilingual schools of the indigenous communities, through the "draw and write" technique. The study sets out to visualize the relationship(s) between the language children used and their representations of the environment in which they live. The total participant sample was two hundred and twenty-five primary school students. The aim is to see whether there is any relationship between the language used and the conception of the children in their environment. The type of methodology used was qualitative, following Wimmer's proposal, with twelve categories emerging. The findings indicate that the choice and characteristics of the elements chosen by children are related to the spontaneous and determined use of a language. In conclusion, not surprisingly, it can be affirmed that with the sample obtained and the methodological design applied, a greater use of non-indigenous language (Spanish) is detected in these indigenous children when they want to show their life and their environment representing a decline of their indigenous language. On the other hand, children who prioritize the indigenous language (Kichwa) tend to project more defined elements and use larger dimensions (larger size) than the elements related to the Kichwa culture; In spite of this, it can be concluded that the use of one or other language does not reflect a departure from the values, organization or cultural elements of these indigenous communities.
\end{abstract}

Keywords Community Schools, Saraguro Culture, Indigenous Language

\section{Introduction}

This article shows the extent of the use of the Kichwa language at early ages through the graphic representation by a sample of indigenous pupils between 5 and 7 years old using the draw and write technique [1]. The studies presented indicate that the samples tend to be made up of more adult populations, ten years old and older [2], which means that this study already represents a step forward in this regard. It is important to take note of the fact that studying only older age groups up to now has made it impossible to analyse the use of language in ages at which it is a key element in the processes of the revitalisation of indigenous languages and as a cultural symbol. This article sets out to provide knowledge concerning the first stages of children's schooling through the analys is of their drawings and the identarian relation they bear to the kich wa language, thus significantly contributing to the existing literature on the subject.

\subsection{Draw-and-Write Technique}

Based on 'draw-and-write', the method is guided by research questions, namely what conceptions do indigenous children make of their cultural environment? And what language do they spontaneously use in these conceptions? The ethical part of the investigation has also been considered as having proceeded with the assent of participating pupils as well as the consent of parents and teachers. It is important to state here that the draw-and write technique was first introduced in the 1980s and has become one of the most common tools for the investigation of children's understanding. It allows the little ones to participate through graphic expression and writing. Also, with 'draw and write', children can express concepts of themselves and the environment [3].It is used to explore children's views on a variety of abstract and conceptual topics such as technology, health, ideal person, themselves, including latest studies on representing the interaction 
between children and clinicians [4] or describing the obesity in Malta for young kids [5].The most appropriate age group for "draw and write" a re young child ren, because their verbal and written skills tend to be less developed and researchers have argued that, at the end of childhood, children prefer written communication and they are no longer involved in the spontaneous production of drawings.

\subsection{Analysis of the Drawings: Literary Contributions}

Graphic language is one of the ways in which very young children most fluently give expression to complex concepts. According to the clas sification formulated [6], it is from the age of 7 onwards that the stage of evolutive attachment to cultural influences begins, and they can be seen to manipulate models intrinsic to their culture. In a pedagogical setting, graphic symbolisation is relegated to a play-related function; however, drawing allows representations of great interest [7]. A significant connection of the current emotional states of pupils of different ages with the shapes and colors they use to compose drawings on the perceptions of the self and of particular environments has been identified. Chacón and Morales [8] found that 4-year-old recreated in their drawings fantastic environments and effortlessly accessed the collective imagination. Benavides [9] correlates the drawings of children between 4 and 12 to the family and discovers that children express more elements than they would verbally. Also, by drawing, children better articulate the cognitive, cultural, political and ecological phases. Another study, taking a different approach, explores 7-year-old children's identification with role models, concluding that children identify more with television characters than with members of their own families; shows the relevance relational and moral aspects have for young children, the relevance of people, actions and objects [10]. Moragon and Martinez [11] state that drawing can promote understanding of children's play with the aim of showing alternatives to the dominant models of physical culture imposed on them since early childhood [12]. A study of the indigenous communities of Paraguay indicated that indigenous children who drew the shapes in which they thought of themselves and their community viewed the family and community differently from the way traditional indigenous community did: language, clothing and aspects of their culture had been replaced by Western trends [13]; Other study with 8-year-old indigenous children found that that indigenous children in northern Ecuador expected to imitate more privileged urban children but continued with their cultural-religious process unaffected; In their drawings, the children expressed their antipathy towards their school; they did not feel respected in their classes, or in the social, cultural, linguistic or ethnic groups that they belonged to [14].

Finally, the Saraguro children show a clear interruption in the intergenerational transmission of the language despite their positive attitude towards the language and observe a predominance of Spanish over all the indigenous languages of the country in children from the Cañar province. There has been a decline in the number of children speaking Kichwa due to the lack of oral literature created in Kichwa, and the Kichwa books available in schools. The use of Kichwa with in families also contrasts with the language used in schools, in the majority of which only Spanish is used [15].

\section{Method}

The methodology was used for the study in qualitative-descriptive [16] with an emergent design [17], which stresses the importance of the theory arising from the data rather than from a system of predetermined categories, and is based on "an open coding from which the categories emerge and then interconnect to produce a theory" [18]. Validity and reliability were provided by using two experts going through the 225 drawings separately to categorize the elements being drawn, following two cycles of categorization. During the first cycle, the two experts came up with 40 different categories, which then were analysed and further refined until the final number of 12 categories was reached.

\subsection{Participants}

The participants in the study are two-hundred twenty-five indigenous children (127 girls and 98 boys) between 5 and 7 in six bilingual intercultural community schools: sixty from the ABC school in the Membrillo community; forty-six from Mushuk Rimak; thirty-four from Inti Raimy; twenty-nine from Inka Samana; and nineteen from the Gera Community in San Francisco.

\subsection{Instrument}

The study is based on emergent data collection theory [19], and protocols, the emphas is being placed on cultural approximation [20]. Using the approach with the children being given freedom to draw, then after a careful analysis of the drawings produced, certain recurring elements are identified, which will constitute the final analytical categories.

The model proposed is used as a reference for the analysis of the use of colour, and the placing and size of objects in the drawings [21]; this procedure was twofold: firstly, the colorurs, shapes and sizes were analysed, particular attention was being paid to the precise ways in which they mimic the real world [22], and secondly in terms of the actual size of each variable in relation to the whole drawing [21,22]. Finally, this study follows the application of categories to analyse the composition of the 
drawings and procedure for the application of factorial analysis techniques and classification [23].

\subsection{Procedure}

In order to obtain the graphic material from the students, a set of six instructions was formulated and shared with the teachers in the six schools taking part in the study. The instructions for the drawings are provided in both Kichwa and Spanish. The instructions follow 5 steps:

a) On an A4 sheet of paper, draw your community.

b) In the drawing of your community you must include yourself.

c) Write the names of the objects which you draw in your drawing (labels)

d) Paint the drawing, and

e) Write your name and class.

In order to assess the spontaneity of the language in instruction c), they are not told which language they should use, and nor are they told which objects they must include. The drawing sessions were conducted in the classrooms and within class-time for each course. No time limit was set for the drawings or for the conclusions, and they were given as much time as they needed.

\section{Results}

\subsection{Organization of the Drawings in Groups}

The 225 drawings are classified, in the first place, according to the language used to label the different elements included (categories of analysis). In this way, four groups were obtained: a) drawings in Spanish; $b$ ) drawings in Kichwa; $c$ ) bilingual in Spanish and Kichwa; and, $d$ ) Unspecified language.

\subsection{Categories}

A total of 12 categories were analysed, equally, for the four groups: 1) sun, 2) countryside, 3) family, 4) house, 5) pets, 6) me, 7) tree, 8) cloud, 9) water, 10) flowers, 11) family gardens and 12) birds. The analysis by category is determined by its size in the drawing. In this way, we can observe the degree of importance that each pupil assigns to the ele ments represented in the drawing [24]. Thus, another variable, corresponding to the size of each category, is introduced: small, medium-sized or large.

\section{Analysis}

The 225 drawings are codified in terms of the four groups according to which they are classified. To each group a letter is assigned, as well the number that corresponds to the number of graphic examples they contain.

\subsection{Group A: Spanish}

This is the most numerous of the four groups, with 104 drawings covering $46.2 \%$ of the total. They are codified from the series (a1) to (a 104). In this group the category that features most often is family, with 60 drawings, representing $60.6 \%$ of the group. In family most of the representations, 24, are small, as can be observed in drawing (a51); 20 are large like example (a15); and 19 medium-sized like drawing (a5). The house category has 29 medium-sized representations like drawing (a25); 22 large as in drawing (a52); and 11 small ones. The tree category appears 40 times, the medium-sized ones like (a26) and the small ones (a28) are more frequent by far than the large ones, which only appear eight times. The sun category follows with 35 occurrences, the small (a1), medium (a22) and large (a30) being of similar size. The Mountain features 29 times: 26 of them large like drawing (a24).

There are 25 drawings, both small and medium, under the pet category; drawing (a30) contains an example of small pet animals and medium-sized are featured in (a18), while the only large example is (a36). The clouds category occurs 15 times, s mall ones like (a27) and medium-sized like (a10). There are also flowers, with 15 drawings, most of them s mall like (a5). Family gardens are included in 13 drawings, as in number (a10). The water category appears 10 times and almost all of them are medium-sized like (a31). The final two categories are birds, 8 times, most of them small (a37) and, the me category occurs 6 times, 3 times small and the others medium-sized, as in (a49).

In Figures 1-7, we can see a clear examp le of the fact that the family category is represented as small, with the house category as medium-sized being the majority in this group.

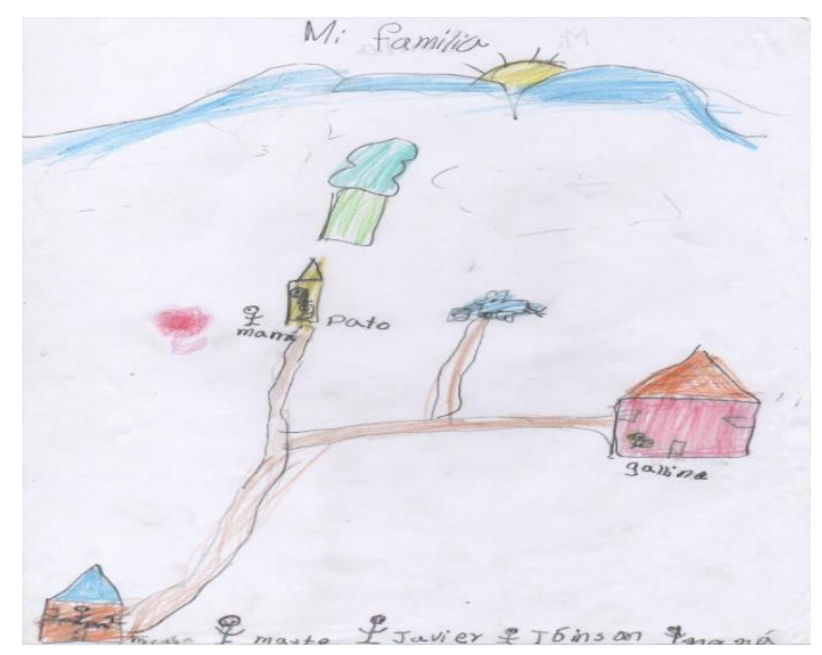

Figure 1. Drawing (a51), six years old 


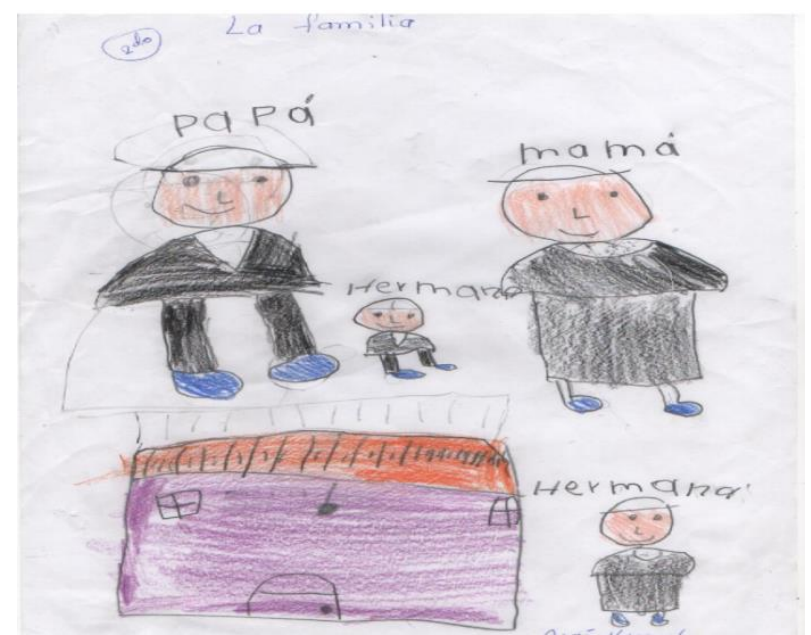

Figure 2. Drawing (a15), five years old

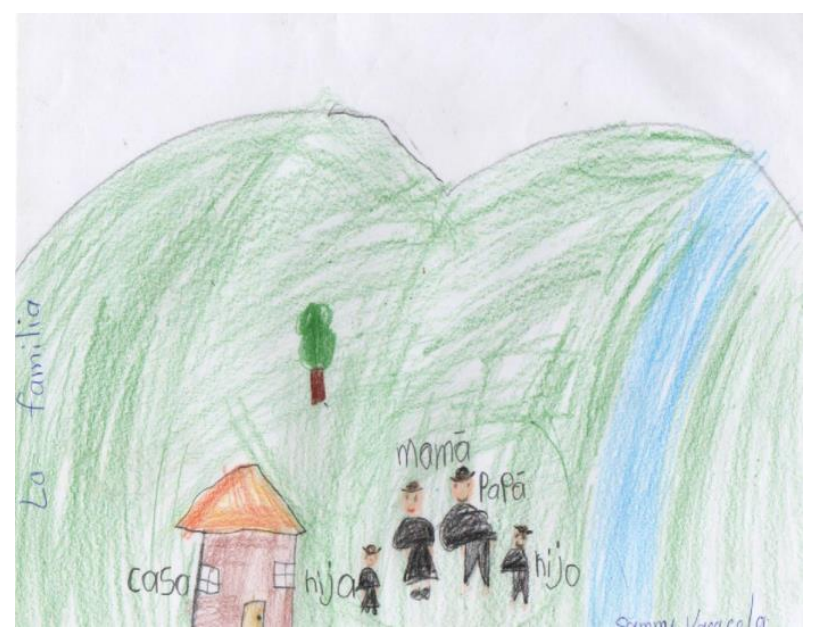

Figure 3. Drawing (a5), seven years old

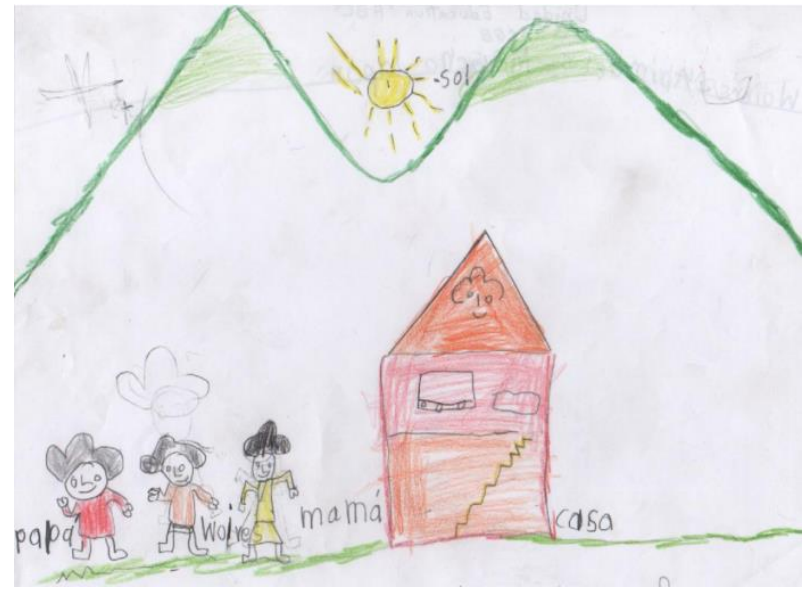

Figure 4. Drawing (a25), five years old

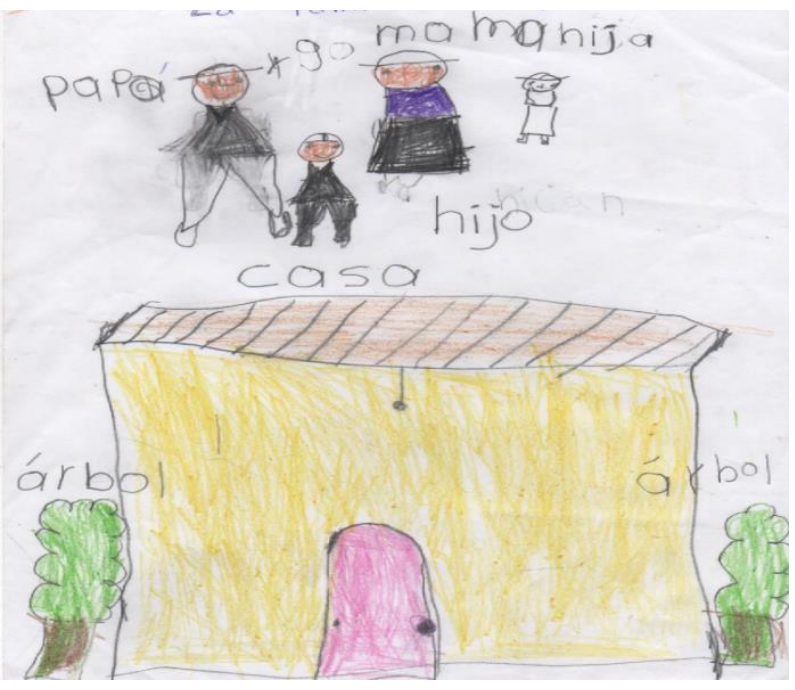

Figure 5. Drawing (a52), six years old

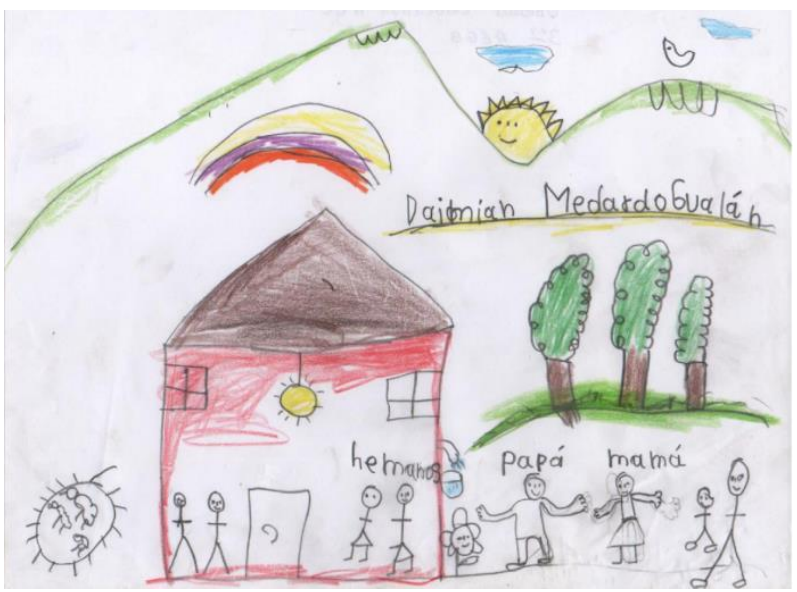

Figure 6. Drawing (a26), seven years old
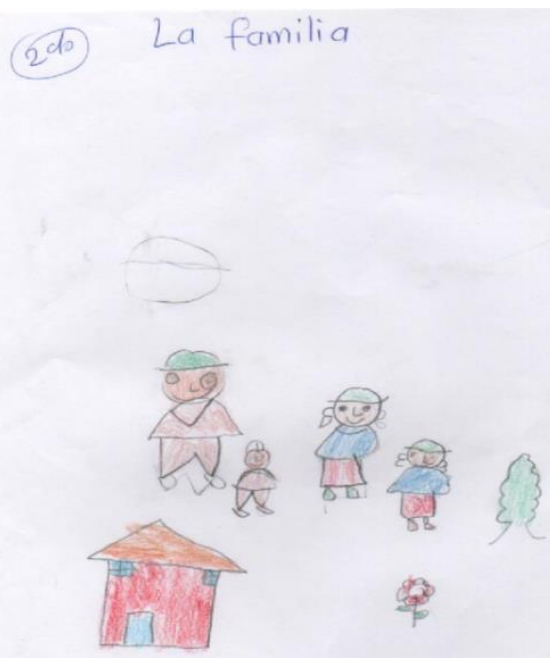

Figure 7. Drawing (a28), five years old 


\subsection{Group B: Kichwa}

Under this group, there are 30 drawings covering 13,3\% of the total. It corresponds to the group with fewest representations of the four. The codes represent the sum total of the drawings with the letter $b$. The house category is the most numerous, with 18 occurrences, an equal number of s mall and large as in (b2) and (b15). The sun category is included in 13 drawings, number (b3), for example, is medium-sized. Drawing (b14) shows a small example of the family category. Then there are trees, with four large in relation to other elements like the sun and house (b4), three medium-sized (b 10) and two small (b8). In the Mountain category, most of the drawings are large, like (b6). There are 8 small representations of family gardens (b3), and of pet animals, all of them also small, as in (b11). There are only 4 examples of 4 elements: clouds (b14), medium-sized, water (b 13) large, flowers (b17) small and birds (b11) small. Interestingly, in this group, the $m e$ category does not appear despite being asked to include themselves.

Figures 8 and 9 feature two categories: house (wasi) is represented as a small/medium if you were to compare to the trees (figure 9) or to the mountains (figure 8) size and the sun as a medium-sized one. These two categories are the most frequently represented in group B, with drawings labelled in Kichwa.

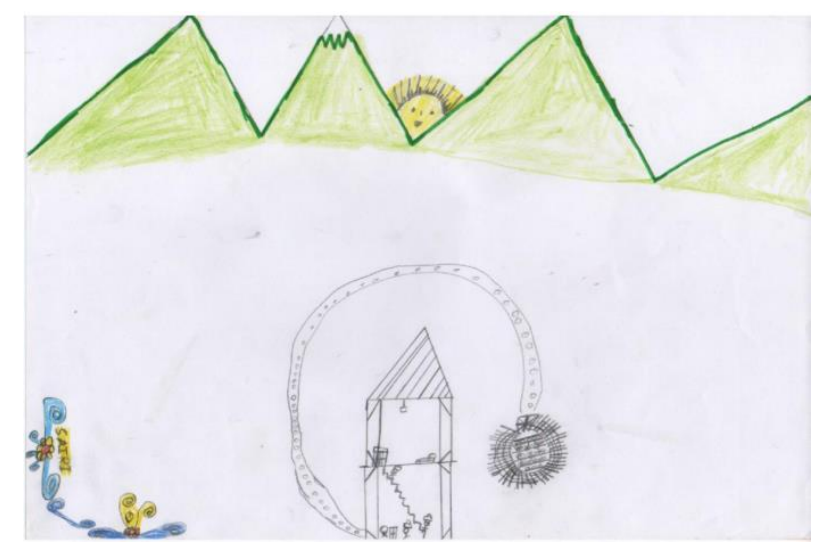

Figure 8. Drawing (b1) six years old

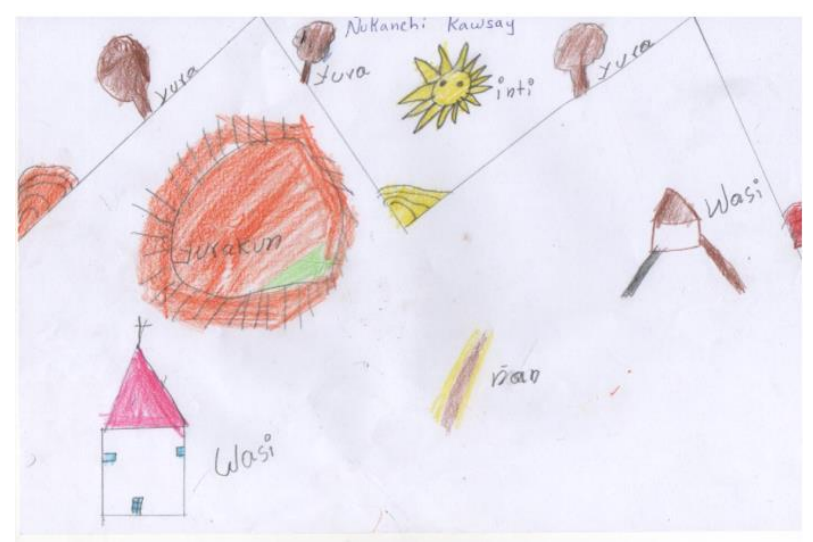

Figure 9. Drawing (b4) seven years old

\subsection{Group C: Billingual}

The third group is made up of 28 drawings covering $12.4 \%$ of the total. They are classified under the letter $c$. There are 17 representations of the house category, most of them large (c 13), with six mediu m-sized examples, as in the case of (c 10). Then there is family, most of them small (c3) and four of them either mediu m (c7) or large (c9). There are ten tree drawings, six large (c6) and four medium-sized (c8). Flowers appear eight times, four medium-sized as in drawing (c1). In the sun category there are four medium-sized drawings like (c5). There are three categories with four drawings: Mountain, pet animals and clouds; the mountains are large, as in picture (c5), the pet animals are medium-sized (c3) and the clouds are large (c11). For the water category, there is one representation for each size: s mall (c 14), medium-sized (c6) and one large one (c12). The me category is also represented, with two small-sized drawings (c3) and (c6). There is one medium-sized drawing in the family garden category (c4) and the bird category is not represented by group C. Figure 10 and 11 we can see an example of a large-size drawing in the house category.

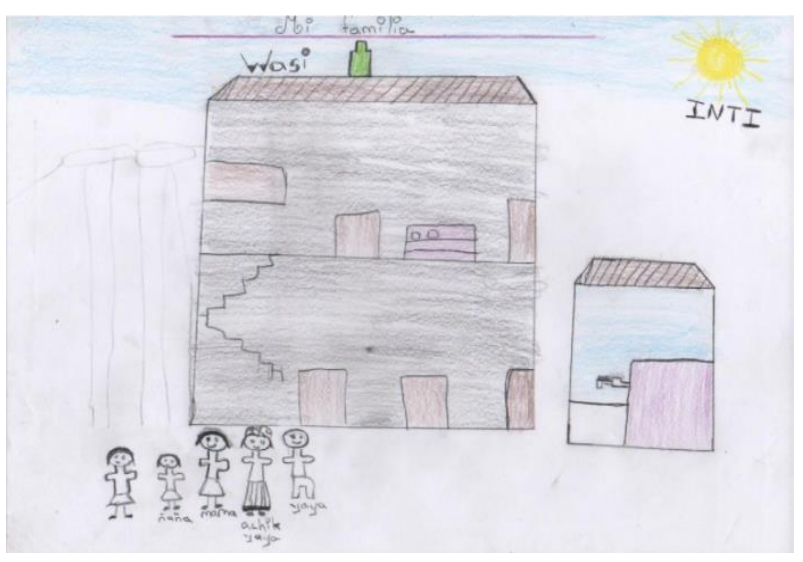

Figure 10. Drawing (c14) six years old

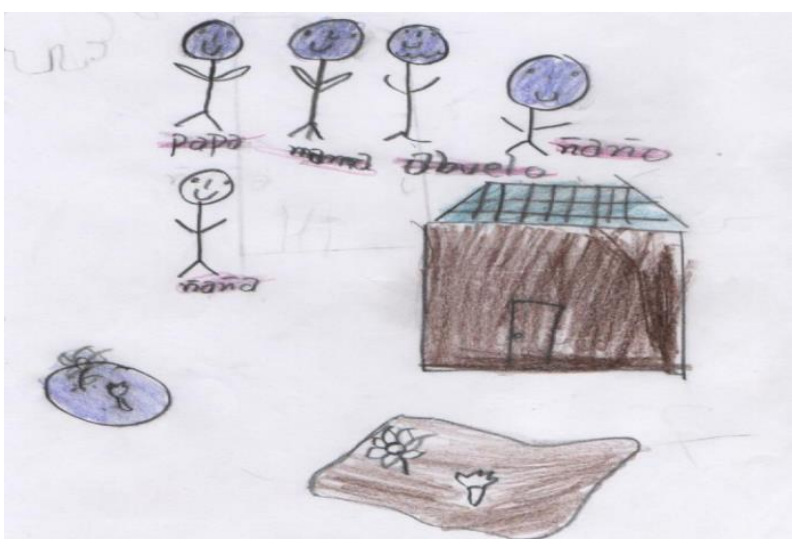

Figure 11. Drawing (c4) five years old

\subsection{Group D: Unspecified Language}

In the last group there are 63 drawings classified under 
the letter $d$ covering $28 \%$ of the total. This is the second most numerous group in terms of graphic representation. The category with the largest representation is the house with a total of 58 drawings, 25 of them large (d48), twenty-four medium-sized (d7) and nine small (d 12). Next is the family category with 48 examples, 19 s mall (d6), 14 medium-sized (d13) and 12 large ones, as in (d1). The next category is Sun, 37 times, sixteen medium-sized (d2), 12 large ones as in drawing (d20) and (d44) representing the small size. The tree category is next with 27 representations, ten large ones (d4), ten small ones (d27) and seven medium-sized ones (d25). After that, the Mountain category with 22 representations, of which 17 are large like (d3). There are three categories, clouds, family gardens and pet animals all with 17 examples. Most of the examples of the first of these categories are medium-sized, as in drawing (d4); almost all the drawings in the second are medium-sized, like (d31); and in the third category ten are small (d25). The flowers category is represented by 11 small (d5) and medium-sized (d3) drawings. Unlike in the other groups, the me category is featured in 10 drawings. Seven of which are small (d2), two large (d13) and one medium-sized. Water appears 5 times, with four large drawings like (d69). Finally, the bird category is represented in small size in (d17) and large in (d30).

Figure 12 offers an example of the fact that the House category is represented by a large and fine-grained detail drawing and is featured in this way in most of the unspecified language.

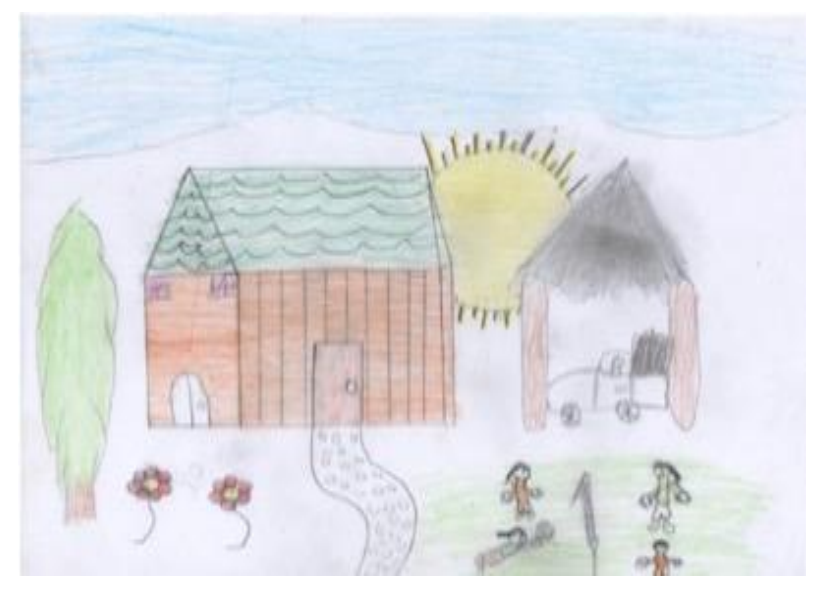

Figure 12. Drawing (d48), seven years old

\section{Discussion}

The discussion is twofold: In the first place, the relationship between the spontaneity of the language and the most constant elements across the four variables; secondly, between the composition of the drawings and the observation of patterns applicable to the study of Kichwa cultural components common to all the groups.

In the group of drawings labelled in Spanish, group A, the most concurring elements that the indigenous children have chosen for their compositions are family and house, followed by the natural elements of their neighbourhood. This is the most numerous group and indicates in the Saraguro children a certain predominance of Spanish over Kich wa in terms of how they perceive things [24] and it also confirms the interruption of intergenerational transmission of Kichwa in the towns of the Andes. Despite their being asked to include themselves, the results show that they barely do so in the drawings, and in the few cases where they do, there is no indication that they see themselves as superior to other family members, like their siblings or grandparents. Thus, we have an individual who conceives and communicates his or her environment as it is, a context configured by the Kichwa culture, which always emphasises the community as a construction within which the collective self is defined. The family always appears with its indigenous characteristics, for whom the children saw themselves as separate from their indigenous identity. The children in the study view the family with its distinctive indigenous features in its forms and activities. The findings also contrast with the view of Ximhai [25] with regard to the influences of the urban context, as the Saraguro child ren, despite being very close to their urban environment, demonstrate a very clear idea of their own cultural identity.

The houses in the drawings have a design that is exclusive to the region; for example, they have tiles which are made of mud and wood. Between the family and the house category there is a strong cultural correspondence in which they both conserve the image and the design of their cultural setting. There is a cultural coherence linking people, actions and objects [26]. The natural elements that the Saraguro children draw symbolise the worldview, culture and landscape representative of the region. These elements contain an inherent knowledge, not only as their indigenous identity, but also as an explanation and a meaning of the world [27]. This reflects a mimesis of the real object. The large mountains, the shiny sun and the abundant trees are a replica of nature, and at the same time is transmitted as cultural icons [28].

On the other hand, in the Kichwa group, group B, the house and the sun are the most frequent elements. The numerical difference with respect to the first group is a little more than three-fold. Two things are worth noticing here, the linguistic antagonism, with Spanish used being the overruling language; and the cultural elements. In the Spanish language, it is the social elements that are predominant, while in Kichwa it is the house, that is to say, the elements that are most closely aligned with the Saraguro culture. This can be explained from the Kichwa culture, because it reflects their way of thinking; it is also comprehensible in terms of the phenomenon which refers to as dysfunctionality [29] which the child experiences between the family language and the school language. This phenomenon is also implied by Enriquez (2015) when he 
refers to the failure of schools when it comes to oral and written production in the indigenous language, and to their failure to include a Kichwa bibliography in the learning and teaching processes.

Although the four groups are antagonistic in terms of language, processes of social and cultural integration, of adaptation of the patterns and harmonious development still come to light [30], because the portraits of the drawings, the environments, the relationships and the cultural distinctive do not get lost in the two groups of drawings, but reassert themselves despite the difference in spontaneous language, and external factors such as the external policies relating to the country's indigenous culture and language.

The greater presence of a specific language is reflected by the prioritising or observing of certain elements. In the case of the Spanish language, the family appears as an element in more than half of the drawings; by contrast, in the case of Kichwa, the predominant elements are those that relate to indigenous culture, like house and sun. Everything is neatly packaged within the collective imagination [31]. In the drawings with bilingual labelling house and family are the most frequent elements. This reinforces the content of group A. After that appear the natural elements of fauna and flora, always in their natural context, and in a real, natural way. The natural elements, while they are less frequent than social or cultural ones, are always present and highlighted in their natural condition and environment, with a certain ecological and cultural connotation [32].

Last but not least, in the group of drawings where the written language is not present, the family, the house, and the sun are the elements which appear more often and followed by the natural elements. The fact that the local, social and cultural elements persist in the Saraguro boys and girls confirms the influence, from the very first years of life in indigenous communities, of the culture of the ethnic group by contrast with the central regions of the Ecuadorian mountain range on indigenous and non-indigenous elements in the formation of children's identities.

The indigenous take has been present across all the variables, and the children include it in all the categories, despite the fact that Spanish language has given rise to such a remarkable linguistic difference. This phenomenon is partly attributable to the homogenisation of the Kichwa language [33], which results in the suppression of non-standard variants that are popular and still part of the everyday speech within families, but which are not taken into account in schools on account of the national plan for bilingual, intercultural community education. This plan sets out to incorporate, not only the native language, but also the intrinsic value of both the indigenous culture and the cultures it is in contact with, as well as the holistic training of the indigenous peoples, the inclusion of indigenous teachers in teaching programmes and a deep appreciation for hereditary knowledge [34]. The me category is not very prominent. When it appears, it is in a balanced emotional and sociocultural context [35]. Indigenous children communicate fee lings of well-being in relation to their environment, and they appear in activities appropriate for their age. This trait also appears in children of the same age, as suggested which explains it as the way in which one sees oneself and projects oneself.

Finally, the results also reflect a contradiction between the Use of language scheme as implemented in the bilingual pedagogical process, and the linguistic reality of the Saraguro children. The pupils at the stage of Cognitive affective and psychomotor reinforcement, between the ages of 5 and 7, should use their native language $50 \%$ of the time Spanish $40 \%$ and a foreign language $10 \%$. However, what the findings show is slightly difference: $46 \%$ of the children use Spanish, barely $13.3 \%$ Kichwa, and $12.4 \%$ use both.

\section{Conclusions}

In conclusion, we can argue that there is a clear predominance of the Spanish language in the drawings produced by indigenous Saraguro pupils, as a result of which, in the spontaneous use of language to name the components of their cultural environment, they prioritise the elements that constitute the community, the family, themselves and the nature in any given drawing. Thus, the family, the house and natural elements, in that order, are much stronger and more recurrent in the children who chose to use only Spanish, or both spanish and Kichwa. By contrast, in the case of the children who spontaneously only used Kichwa, the order is modified in that they prioritise first the house, then the sun and then the family and the natural elements. The Kichwa language in children is more closely associated with the cultural conception of the environment, whereas Spanish is more linked to social organis ation.

While it is true that the spontaneous use of language reflects the importance hierarchies of the social, cultural and natural environment in a bilingual context, and in a context of cultural contact, this does not mean that Saraguro children are inclined towards a community identity that is shaped by superficial factors, or factors of social organisation, imposed from the outside, or in accordance with model projections configured by some kind of culturalisation. On the contrary, in their drawings, children compose scenarios that are fulfilled with elements that are native to their own culture, with the forms, landscapes, customs, social and social and work-related activities that comprise their indigenous identity. These findings are of crucial, because it proves that they feel deeply attached to the cultural identity that is constructed within the family and the indigenous community from which they derive their sense of belonging. 


\section{Acknowledgements}

The Scholarship program: "Universities of Excellence 2015" promoted during the presidency of Rafael Correa Delgado.

\section{REFERENCES}

[1] J. McWhirter. The draw and write technique as a versatile tool for researching children's understanding of health and well-being, International Journal of Health Promotion and Education, Vol. 52, No. 5, 250-259, 2014.

[2] L. López, F. García, Atlas sociolinguiístico de pueblos indígenas en América Latina. Capítulo VII Ecuador Andino. FUNPROEIB, Bolivia, 2009

[3] M. Tatlow-Golden, S. Guerin. My favourite things to do' and 'my favourite people: Exploring salient aspects of children's self-concept. Childhood. Vol. 17, No. 4, 545-562, 2010.

[4] G. Bry an. M. Bluebond-Langner, D. Kelly, S. Kumpunen, K. Oulton, F. Gibson. Studying Children's experiences in Interactions with Clinicians: Identifying methods fit for purpose. Qualitative Health Research, Vol. 2, No. 3, 393-403, 2019.

[5] G. Martin. Draw (me) and tell: use of children's drawings as elicitation tools to explore embodiment in the very young. International Journal of Qualitative methods. Vol 18, No. $13,1-19,2019$.

[6] S. W. Ives, H. Gardner, Cultural influences on Children's Drawings. University Press, EE-UU, 1984.

[7] A. Maeso. Influencia de los ámbitos familiar, educacional y mediático en la adopción de identidades por los niños y las niñas a través de sus dibujos. Arte, Individuo y Sociedad, Vol. 20, No. 14, 107-127, 2008.

[8] P. Chacón, X. Morales. El rol del monstruo en las narraciones audiovisuales dirigidas a los niños y niñas. Un análisis semiótico cultural a través del dibujo infantil. Foro de Educación, Vol. 13, No. 4, 51-68, 2015.

[9] L. Benavides. Educación para la Paz, el respeto al medio Ambiente y la integración socio-cultural, a través de las artes. Arte, Individuo y Sociedad, Vol. 18, No. 4, 1131-5598, 2016.

[10] M. Aguilar, J. Mercon y, E. Silva. Percepciones de niños y niñas para la conservación de los primates mexicanos. Sociedad y Ambiente, vol. 12, No. 2, 99-118, 2016.

[11] A. Leal. Dibujos infantiles, realidades distintas: un estudio sobre simbolización gráfica y modelos organizadores. Revista de Psicología da UNESP, Vol. 1, No. 5-19, 2010.

[12] F. Moragón, V. Martínez. Juegos de niñas y juegos de niños: Estudio sobre la representación del juego infantil a través del dibujo. Educación, Vol. 1, No. 2, 1-17, 2016.

[13] A. Colombres. La colonización cultural de la América indígena. McGraw-Hill, Argentina, 2004.
[14] M. González. Las escuelas clandestinas en Ecuador. Raíces de la educación indígena intercultural. Revista. Colombiana de Educación, Vol. 69, No. 10, 75-95, 2015.

[15] M. Burneo. Breve análisis de la vitalidad del kichwa en las comunidades de lagunas y Ñamarín de la parroquia Saraguro. Pontificia Universidad Católica del Ecuador. Ecuador, 2016.

[16] L. Cohen, L. Manion, K. Morrison. Research methods in Education. Sixth Edition. Routledge, England, 2018.

[17] J. Kross, A. Gius. Elements of research questions in relation to qualitative inquiry. The qualitative report, Vol. 24, No. 1, 24-30, 2019.

[18] R. Hernández, C. Fernández, P. Baptista. Metodología de la investigación (6 $6^{\mathrm{a}}$ ed). D.F.: McGraw-Hill, México, 2010.

[19] L. Izquierdo, Análisis de los dibujos infantiles. Universidad de Valladolid, España, 2015.

[20] Y. Solovieva, L. Quintanar-Rojas. Drawing in Pre-school Children as a Strategy for Preparation for School. British Journal of Education, Society \& Behavioural Science, Vol. 9, No. 13, 50-61, 2015.

[21] A. Molina. El dibujo infantil: Trazos, colores e historias que nos hacen reflexionar y aprender. Revista Electrónica Educare, Vol. 19, No. 15, 167-182, 2015.

[22] M. Wimmer. The complete guide to children's drawing. Createspace Independent Publishing Platform, Middletown, 2014.

[23] M. Castellano, N. Roselli, Estudio exploratorio de la colaborativa infantil en la realización de dibujos libres. Pensamiento psicológico, Vol. 12, No. 10, 37-56, 2014.

[24] P. Enríquez, El rol de la len gua kichwa en la construcción de la identidad en la población indígena de Cañarquito. Pontificia Universidad Católica del Ecuador, Ecuador, 2015.

[25] R. Ximhai. Dibujo e identidad infantil entre poblaciones indígenas mexicanas y del centro-oeste brasileño. Revista de Sociedad, Cultura y Desarrollo Sustentable Vol. 4, No. 1, 51-67, 2011.

[26] M. Tatlow-Golden, S. Guerin. My favourite things to do' and 'my favourite people': Exploring salient aspects of children's self-concept. Childhood, Vol. 17, No. 4, 545-562, 2010 .

[27] J. Inuca. Genealogía de alli kawsay/sumak Kawsay (vida buena/vida hermosa) de las organizaciones kichwas del Ecuador desde mediados del siglo XX. Estudios étnicos latinoamericanos y caribeños, Vol. 12, No. 13, 155-176, 2017.

[28] M. Meza, S. Anchondo. La formación del carácter en los indígenas mexicanos. Continuidades, rupturas y reivindicaciones. Estudios sobre educación, Vol. 37, No. 10, 33-49, 2019.

[29] M. Llambo, Literatura oral kichwa en la comprensión y expresión del lenguaje de los niños y niñas de educación inicial. Universidad Técnica de Ambato, Ecuador, 2015.

[30] C. Golomb. Child Art in Context: A Cultural and Comparative Perspective. American Psychological 
Association, EE-UU, 2002.

[31] J. McWhirter. The draw and write technique as a versatile tool for researching children's understanding of health and well-being, International Journal of Health Promotion and Education, Vol. 52, No. 5, 250-259, 2014.

[32] S. Gabhainn, C. Kelleher. The Sensitivity of the Draw and Write Technique. Health Education Vol. 102, No. 2, 68-75, 2002.

[33] K. Grzech. Es necesario elegir entre la estandarización de las lenguas minoritarias y la vitalidad de sus variedades? Estudio de caso del kichwa de Alto Napo. Disponible en: http://www.redaly c.org/articulo.oa? $\mathrm{id}=1345 / 13455339300$ $2,2017$.

[34] M. Recasens, J. Recasens. Dibujo Infantil y Personalidad Cultural de la Isla de San Andrés. Revista Colombiana de Antropología, Vol, 13, No. 12, 4-14, 1994.

[35] C. Dell Clark. In a younger voice: Doing child-centered qualitative research. Oxford University Press, England, 2011. 